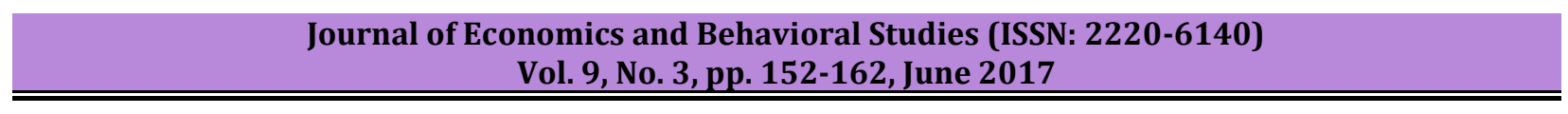

\title{
Savings Mobilization and Financial Development during the Multicurrency Regime Period in Zimbabwe
}

\author{
Kunofiwa Tsaurai \\ University of South Africa, Pretoria, South Africa \\ tsaurk@unisa.ac.za, kunofiwa.tsaurai@gmail.com
}

\begin{abstract}
This paper seeks to investigate the relationship between savings and financial development in Zimbabwe using both autoregressive distributive lag (ARDL) and vector error correction model (VECM) approaches for comparison purposes with monthly time series data from January 2009 to August 2015. Four distinct hypotheses emerged from the literature and these are the savings-led financial development, financial development-led savings, feedback effect and the insignificant/no relationship hypothesis. The existence of diverging and contradicting views in empirical literature on the subject matter is evidence that the linkage between savings and financial development is still far from being concluded. Both F-Bounds and Johansen co-integration tests observed that there is a long run relationship between savings and financial development in Zimbabwe. What is even more unique about this study is that both ARDL and VECM noted the presence of a bi-directional causality relationship between savings and financial development in the short and long run in Zimbabwe. The implication of this study is that in order to increase economic growth, Zimbabwe authorities should increase savings mobilization efforts in order to boost financial development, which in turn attracts more savings inflow into the formal financial system.
\end{abstract}

Keywords: Savings; Financial Development; ARDL; VECM; Zimbabwe

\section{Introduction}

Theory states that savings contribute towards economic through its stimulating effect on investment activities and financial sector development (Lucas, 1988; Romer, 1986). On the other hand, the supplyleading hypothesis founded by Schumpeter (1911) and supported by Goldsmith (1969) and McKinnon (1973) argued that a financial sector mobilize savings, diversify risk and efficiently allocates capital, among other functions. In a bid to approve or disapprove this theory, several empirical studies which investigated a direct relationship between savings and financial development then followed. Their findings fell under four distinct categories, namely the savings-led financial development, financial development-inspired savings mobilization, bi-directional causality and no/insignificant relationship between financial development and savings. The empirical work on the savings-financial development hypothesis is still an unsettled matter considering the diverging and contradicting findings emanating from such studies. Besides, previous time series studies on savings and financial development linkages have mainly used data whose number of observations is just above the minimum required, used at most one econometric estimation technique, either used quarterly or annual time series data, avoided economic and political volatile countries such as Zimbabwe. It is against this backdrop that this paper carried out an empirical investigation of the interlinkages between savings and financial development in the case of Zimbabwe. This study adds value to the literature as this is the first study the author is aware of to examine the linkage between savings and financial development using monthly time series data. The comparison of results from two different econometric estimation techniques (ARDL and VECM) in a single study makes this paper a worthwhile contribution to the literature. This is the first study the author is aware of, done in a country: (1) still reeling from a period of hyperinflation during which time the people's savings in financial institutions had been completely wiped out and (2) which had adopted dollarization as a currency policy or in a multicurrency regime. The findings from this study will help Zimbabwean authorities to develop a raft of savings mobilization or financial development measures aimed at boosting future economic growth of the country. The paper is structured as follows: The second section focuses on the theoretical perspective, section three reviews empirical literature whereas section four shows and discusses the trends on savings and financial development developments in Zimbabwe. The fifth section explains the research methodological framework, results and interpretation whereas the sixth section concludes and suggests areas for future research. 


\section{Literature Review}

The endogenous growth model developed by Pagano (1993) which was expanded by Bailliu (2000) argued that banks increase their efficiency as they provide more financial intermediation services. This increased efficiency leads to the fall in the service costs that they charge for their services thus pushing up the portion of savings directed towards investment and economic growth. Schumpeter (1911) who is the founder of the finance-led growth hypothesis (supply-leading hypothesis) noted that a developed financial sector provides financial services such as savings mobilization, risk diversification and the allocation of capital in an efficient manner that accelerate economic growth. In support of the Schumpeter view, Goldsmith (1969), McKinnon (1973), Shaw (1973) and King and Levine (1993) showed that financial sector spur economic growth through mobilizing savings and allocating them towards production, reducing information and transactions costs. Grossman (1976) argued that a stock market is an avenue through which savings are pooled together and then efficiently allocated to competing productive sectors of an economy. Edo (1995) referred an investment in financial securities as a way of channeling savings to the productive but deficit sectors of the economy. On the other hand, endogenous growth theorists such as Lucas (1988) and Romer (1986) noted that savings stimulate investment activities through the financial sector hence positively influencing economic growth.

Empirical Literature: Previous researchers' findings on the linkage between savings and financial development falls into four distinct categories, namely the savings-led financial development, financial development-led savings, feedback effect and insignificant/no relationship hypothesis as discussed next. The savings led financial development hypothesis resonates with findings from studies done by Bonser-Neal and Dewenter (1999), Fry (1980) and Odhiambo (2008), among others. Using panel data analysis with data from 1982 to 1993, Bonser-Neal and Dewenter (1999) studied the relationship between financial development and savings mobilization in 16 countries. Stock market development was positively but non-significantly affected by higher savings level when countries which were characterized by extreme stock market values were excluded from the study (Bonser-Neal and Dewenter, 1999:376). The same study observed that savings were found to have positively and significantly impacted on stock market development across all the 16 countries. According to Fry (1980), higher savings improve the quantity of real money demand and real supply of credit, which in turn boost economic growth. The same study noted that increased savings which pushes up levels of investment result two outcomes: (1) increased efficiency of the financial sector through lowering of interest rates and (2) higher investment and financial intermediation activities which also spur economic growth. Odhiambo (2008) examined the relationship between savings, financial depth and economic growth in Kenya using the co-integration and error correction frameworks. The findings are threefold: (1) savings improved financial development, (2) savings mobilization was positively influenced by the higher levels of economic growth and (3) economic growth positively affected financial development in Kenya.

Empirical studies which supported the financial development-led savings perspective were done by a number of researchers. In a study of the impact of financial reforms on savings, investment and GDP in Ghana using ordinary least squares (OLS), Asamoah et al. (2008) found out that savings were positively and significantly affected by financial sector reforms. Using ARDL, with annual time series data (1970-2008), Gungor et al. (2014) investigated the impact of financial development on savings in Turkey. Their study revealed that savings were positively Granger caused by financial development in Turkey during the period under study. Sahoo and Dash (2013) compared the influence of financial development on savings between pre and post reforms period in South Asia using panel data analysis with data ranging from 1975 to 2010. Their study found out that financial development positively and significantly influenced private savings, foreign savings, agriculture and per capita income in South Asia during both pre and post reform periods. Ewetan et al. (2015) studied the long run linkage between financial development and domestic savings in Nigeria using the ARDL approach with annual time series data ranging from 1980 to 2012.The two variables were found to be cointegrated and that financial development played a significant positive role in influencing domestic savings mobilization in Nigeria. Using panel co-integration analysis, Kelly and Mavrotas (2008) observed that financial sector development had a positive influence on savings in majority of African countries that formed part of the study. Financial development was an important factor in that positively influenced savings mobilization in Pakistan (Khan and Hasan, 1988:706). 
Using primary data gathered using questionnaires and interviews; Oloyede (2008) studied the interlinkages between savings, informal financial development and rural development in the Ekiti state of Nigeria. Informal financial development played a bigger role in comparison to the formal financial sector in mobilizing savings for rural development in the Ekiti state of Nigeria. However, Husien (2007) explored the relationship between savings, financial development and economic growth in Libya using quantitative data analysis with time series data. Financial development as proxied by credit to the private sector either negligibly affected savings mobilization or non-significantly influenced savings in the long run in Lybia. The same study showed that economic growth boosted savings levels and financial sector development in Lybia. Whilst higher income levels and real interest rates were found to have had a positive influence on savings mobilization, the implementation of financial sector reforms negatively affected savings in Bangladesh (Chowdhury, 2001:4). Quartey (2005) studied the relationship between savings mobilization, financial development and poverty reduction using time series data analysis with data from 1970 to 2001. There are two findings to this study: (1) a negligible impact of financial development on savings mobilization and (2) financial development decreased poverty levels in a non-significant manner.

Baya (2014) studied the linkage between savings and financial development in emerging Asian countries using panel regression analysis with data from 1992 to 2011. Financial development, real interest rate and economic growth were found to have had an independent positive and significant impact on domestic savings in emerging Asian countries. In a study of the determinants of savings, Ang (2011) found out that financial depth and increased banking sector density were the two key factors that encouraged savings mobilization in Malaysia. Hussein et al. (2017) examined the relationship between real interest rate, financial development and private savings in Egypt using vector error correction model (VECM) with quarterly data ranging from 1991 to 2010. Their study observed that private savings were positively and significantly influenced by financial development and real interest rates in the long run in Egypt. Using the Generalized Methods of Moments (GMM) and data from 1999 to 2010, Raheem and Oyinlola (2016) studied the interlinkages between financial development, savings and investment in 37 Sub-Saharan African (SSA) countries. The finding was that improved financial development helped in the mobilization of more savings, which in turn accelerated the investment capacity of SSA countries. The finding resonates with Adeniyi and Egwaikhide (2013) whose study showed that financial development as proxied by credit to the private sector helped in mobilizing savings for investment purposes in 20 SSA countries. Other recent work which supported the financial development-led savings mobilization hypothesis was carried out by Adenutsi (2011).

The feedback effect hypothesis was supported by Rezaei et al. (2014). The latter explored the interrelationships between economic growth, savings and financial development in Iran using the ARDL approach with annual time series data from 1973 to 2012. They noted that a bi-directional relationship existed between (1) financial development and savings, (2) financial development and economic growth and (3) savings and economic growth in Iran both in the long and short run. Empirical studies which resonate with the no relationship hypothesis include those which were done by Rehman et al. (2015). Their study examined the interlinkages between savings, economic growth and financial development in Bahrain using Vector Autoregression (VAR) approach with time series data between 1981 and 2013. Using Johansen cointegration test, the study failed to establish any kind of long run relationship between savings, financial development and economic growth in Bahrain during the period under study.

Savings and Financial Development Trends for Zimbabwe: According to Reserve Bank of Zimbabwe (2017) database, both savings and credit to the private sector in Zimbabwe showed a consistently upward trend between January 2009 and August 2015 (see Figure 1 and 2).Savings went up from US\$41.06 million in January 2009 to US $\$ 140.97$ million in December 2009, representing a massive $243.06 \%$ increase whilst credit to the private sector surged by $569.58 \%$, from US $\$ 104.59$ million in January 2009 to US $\$ 700.31$ million in December 2009. Savings and credit to private sector for Zimbabwe increased by $104.58 \%$ and $139.49 \%$ respectively during the period between December 2009 and December 2010 before savings recorded another increase from US $\$ 288.40$ million in December 2010 to US $\$ 318.37$ billion in December 2011 and credit to private sector gaining from US\$1 677.20 million in December 2010 to US\$2 755.04 in December 2011. 


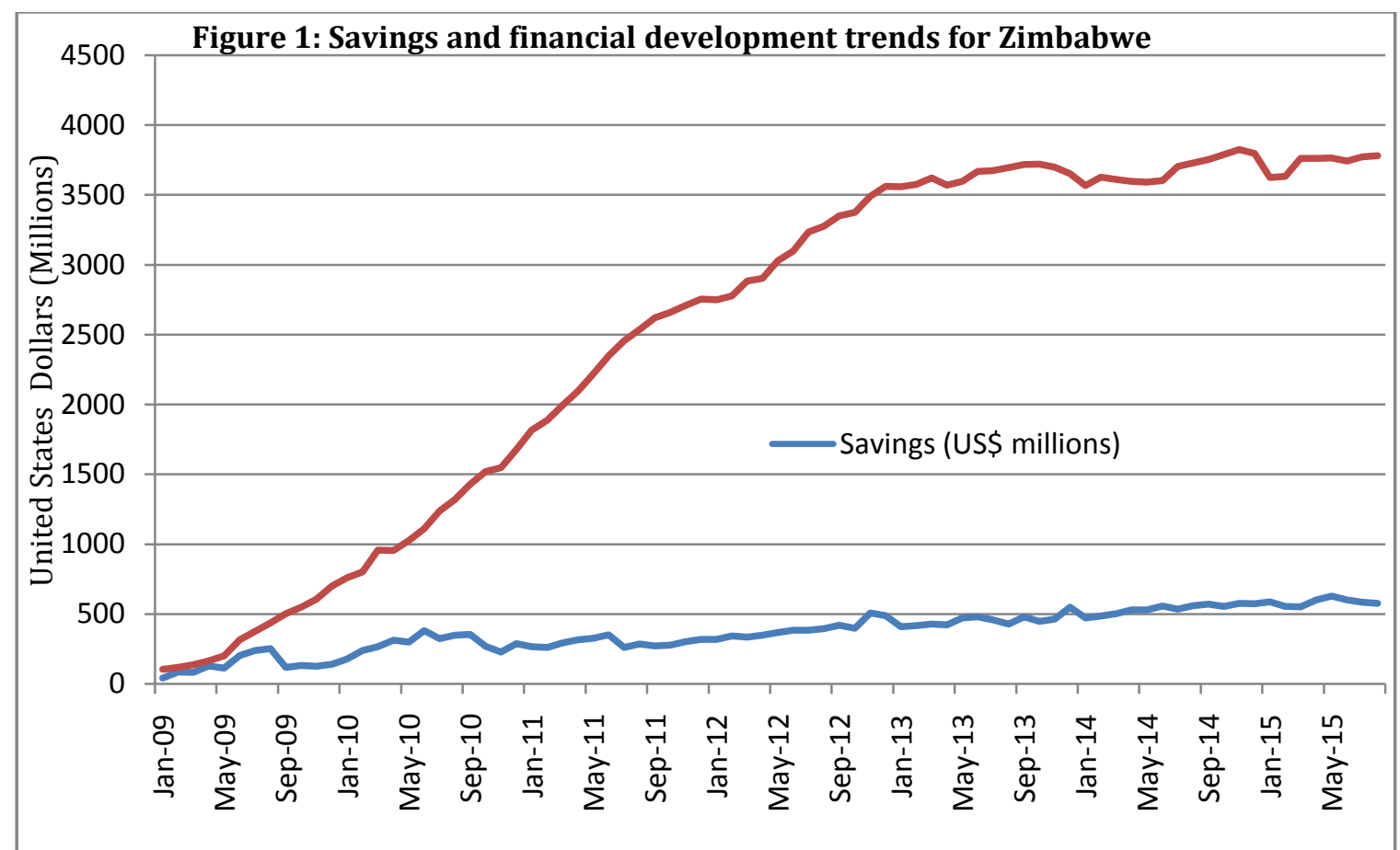

Source: Data from Reserve Bank of Zimbabwe website (www.rbz.co.zw)

Savings went up from US $\$ 318.37$ million in December 2011 to US\$488.52 million in December 2012, increased by $12.18 \%$ during the subsequent 12 -month period before further marginally going up by $4.59 \%$, from US $\$ 548.03$ million in December 2013 to US $\$ 573.20$ million in December 2014. On the other hand, credit to the private sector in Zimbabwe went up from US\$2 755.04 million in December 2011 to US\$3 560.69 million in December 2012, representing a $29.24 \%$ surge, marginally increased by $2.51 \%$ during the 12 -month period from December 2012 to December 2013 and then further went up by a 4.01\%, from US\$3 650.06 million in December 2013 to US\$3 796.27 million in December 2014. Lastly, the 8-month period between December 2014 and August 2015 saw savings going up by $0.55 \%$ to end at US $\$ 576.36$ million whilst credit to the private sector plummeted by 0.41\%, from US\$3 796.27 million in December 2014 to US\$3 780.59 million in August 2015. The general trend observed from Figure 1 and 2 is that both savings and credit to the private sector developments in Zimbabwe moved in tandem with each other during the period under study. The weakness of trend analysis is that although it shows the direction of movement of the variables under study, it cannot tell whether there is a long run relationship or the direction of causality between the variables. The weakness is comprehensively addressed by the use of econometric techniques (see section 5).

\section{Methodology}

Data description, variables definition and a priori expectation: Using monthly time series data (from January 2009 to August 2015) obtained from the Reserve Bank of Zimbabwe website (www.rbz.co.zw), this study examined the relationship between savings and financial development in Zimbabwe during the multicurrency regime period. Savings (US\$ millions) and credit to the private sector (US\$ millions) data were used to represent savings and financial development respectively. Since the data for both savings and credit to the private sector was in millions of United States dollars, this study first converted it to natural logarithms before analysis in order to remove any high standard deviations, outliers and abnormal values which could cause inconsistency and auto-correlation bias, consistent with Hair et al. (2014:80). A priori, financial development is expected to have an influence on savings in line with Schumpeter (1911), McKinnon (1973), Shaw (1973), among others. Following Romer (1986) and Lucas (1988), savings can also positively influence financial sector development. On data cleaning, the autocorrelation which characterized the data at level was addressed at first difference. 


\begin{tabular}{l} 
Journal of Economics and Behavioral Studies (ISSN: 2220-6140) \\
Vol. 9, No. 3, pp. 152-162, June 2017 \\
\hline \hline
\end{tabular}

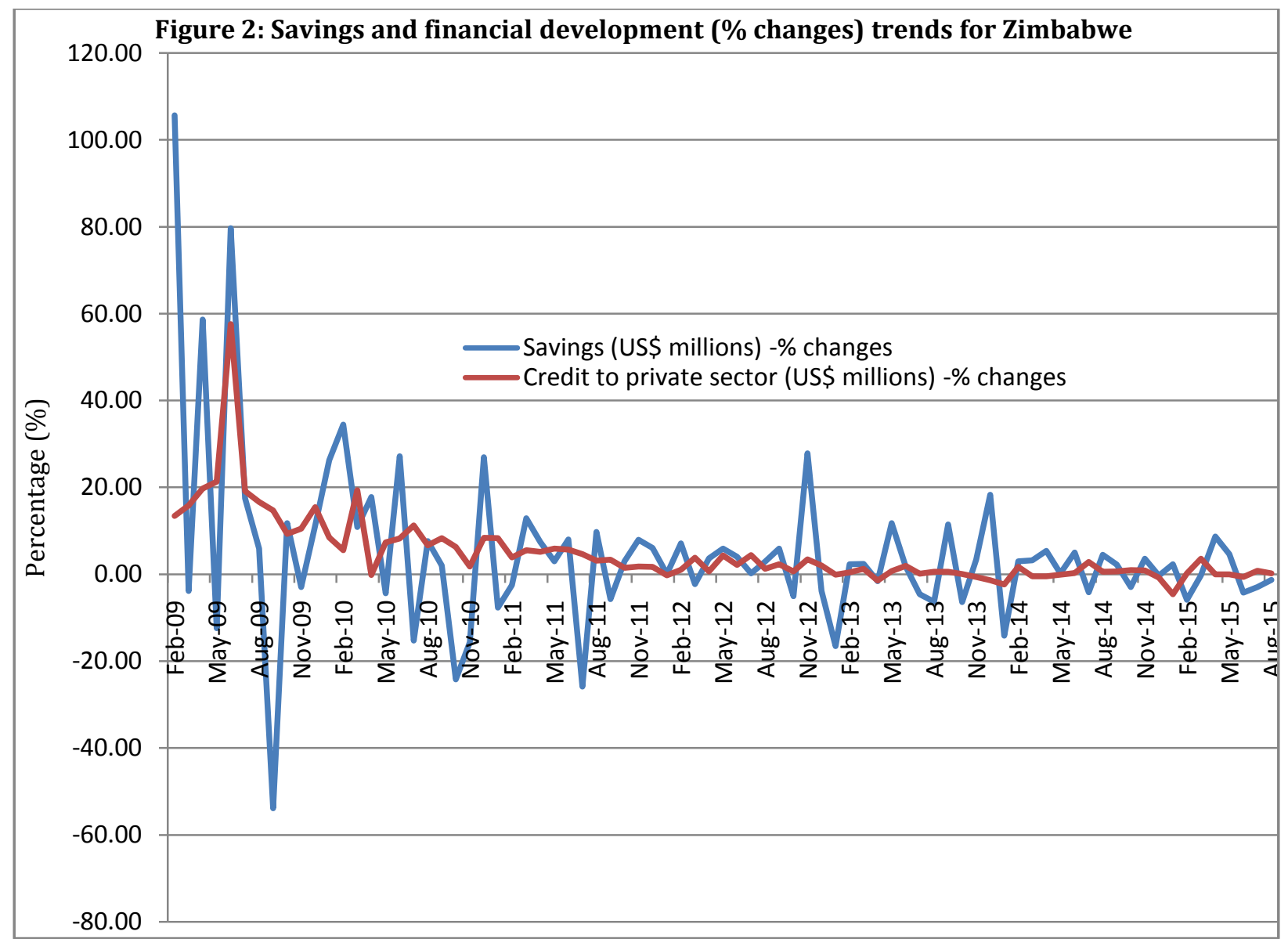

Source: Data from Reserve Bank of Zimbabwe website (www.rbz.co.zw)

Unit root testing: In line with Odhiambo (2008), unit root tests were done in order to establish the characteristics of time series data before the existence of a long run relationship between savings and financial development was estimated. Consistent with Kapingura and Alagidede (2016), this paper used Augmented Dickey Fuller (ADF) and Philips-Perron (PP) to check the stationarity of savings and financial development data and to find out the order of integration of the variables.

Table 1: Stationary Tests of savings and credit to the private sector data at level

\begin{tabular}{lll}
\hline Variable & Test Statistic - None & Critical Values
\end{tabular}

Stationarity Tests of Variables on levels - Augmented Dickey-Fuller - Test

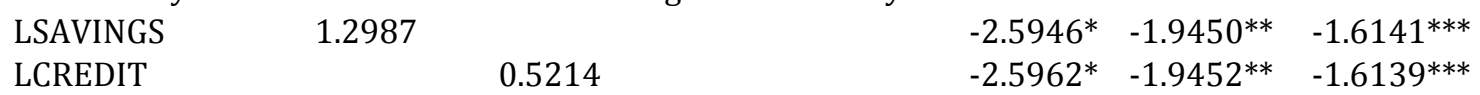

Stationarity Tests of Variables on levels - Phillips-Perron (PP) Test

$\begin{array}{lllll}\text { LSAVINGS } & 1.3572 & -2.5946^{*} & -1.9450^{* *} & -1.6141^{* * *} \\ \text { LCREDIT } & 2.0119 & -2.5946^{*} & -1.9450^{* *} & -1.6141^{* * *}\end{array}$

Note: ${ }^{*}, * *$ and ${ }^{* * *}$ denote $1 \%, 5 \%$ and $10 \%$ levels of significance, respectively.

Table 1 results show that both savings and credit to the private sector data sets were not stationary at level thus making it necessary to check for stationarity at first difference (see Table 2). 
Table 2: Stationary Tests of savings and credit to the private sector data at first difference

\begin{tabular}{|c|c|c|c|c|}
\hline \multirow{2}{*}{\multicolumn{5}{|c|}{$\begin{array}{lcc}\text { Variable } & \text { Test Statistic - None } & \text { Critical Values } \\
\text { Stationarity Tests of Variables on first Difference - Augmented Dickev-Fuller - Test }\end{array}$}} \\
\hline & & \multicolumn{3}{|c|}{ Stationarity Tests of Variables on first Difference - Augmented Dickey-Fuller - Test } \\
\hline DLSAVINGS & -10.9223 & $-2.5949^{*}$ & $-1.9450^{* *}$ & $-1.6141^{* * *}$ \\
\hline DLCREDIT & -2.4902 & $-2.5962^{*}$ & $-1.9452^{* *}$ & $-1.6139 * * *$ \\
\hline \multicolumn{5}{|c|}{ Stationarity Tests of Variables on first Difference - Phillips-Perron (PP) Test } \\
\hline DLSAVINGS & -10.8068 & $-2.5949 *$ & $-1.9450^{* *}$ & $-1.6141^{* * *}$ \\
\hline DLCREDIT & -2.9017 & $-2.5949 *$ & $-1.9450^{* *}$ & $-1.6141^{* * *}$ \\
\hline
\end{tabular}

Note: ${ }^{*}, * *$ and ${ }^{* * *}$ denote $1 \%, 5 \%$ and $10 \%$ levels of significance, respectively.

The fact that the test statistic value was smaller than critical values in Table 2 shows that savings and credit to the private sector data was stationary at first difference and therefore integrated of order 1 . This condition satisfied (not integrated of an order above 1) by the data paved way for further econometric analysis as all what was needed was to difference the data series once in order to make them stationary.

Determination of the optimum lag length: The next step was to determinate the optimum lag length since the data series had satisfied the stationary requirements (at most integrated of order 1). The fact that the lag length impact on the power of accepting or rejection of the results makes its determination very important before any further analysis is done, in line with Kapingura (2014:49). Table 3 results show that the lag length of 5 was found as the optimum.

Table 3: Lag length selection criteria

\begin{tabular}{llll}
\hline Number of lags & AIC & SC & HQ \\
\hline 6 & -4.6300 & -4.1594 & -4.4424 \\
5 & $-4.6747^{*}$ & $-4.2699^{*}$ & $-4.5132^{*}$ \\
4 & -3.8659 & -3.5260 & -3.7302 \\
3 & -3.6803 & -3.4043 & -3.5699 \\
2 & -3.6227 & -3.4097 & -3.5375 \\
1 & -3.6085 & -3.4574 & -3.5480 \\
\hline
\end{tabular}

Notes:

AIC: Akaike information criteria

SC: Schwarz information criteria

HQ: Hanna-Quinn information criteria

FPE: Final prediction error

LR: Sequential modified LR test statistic

*Shows lag length chosen by the criteria

ARDL-bounds Co-Integration Tests: The ARDL framework employed for the purposes of this study is as follows, following Tsaurai and Odhiambo (2013), Odhiambo (2010); Narayan and Smyth (2008).

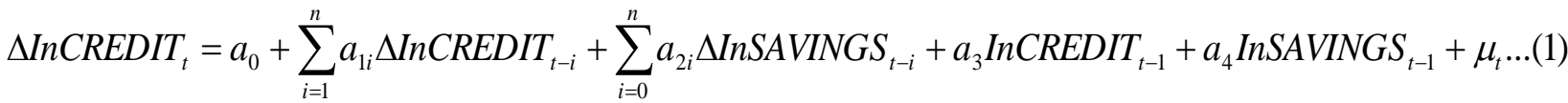

$$
\begin{aligned}
& \Delta \text { InSAVINGS }_{t}=\beta_{0}+\sum_{i=1}^{n} \beta_{1 i} \Delta \operatorname{InSAVINGS}_{t-i}+\sum_{i=0}^{n} \beta_{2 i} \text { InCREDIT }_{t-i}+\beta_{3} \text { InCREDIT }_{t-1}+\beta_{4 I I n S A V I N G S} \text { In-1 }_{t}+\mu_{t}
\end{aligned}
$$

Where: In CREDIT = Log of CREDIT variable; In SAVINGS= Log of Gross Domestic Savings; $\Delta=$ first difference operator.

The F-Bounds test was applied on equation 1 and 2 (see results in Table 4). 


\section{Results}

Table 4: F-Bounds Test for co-integration results

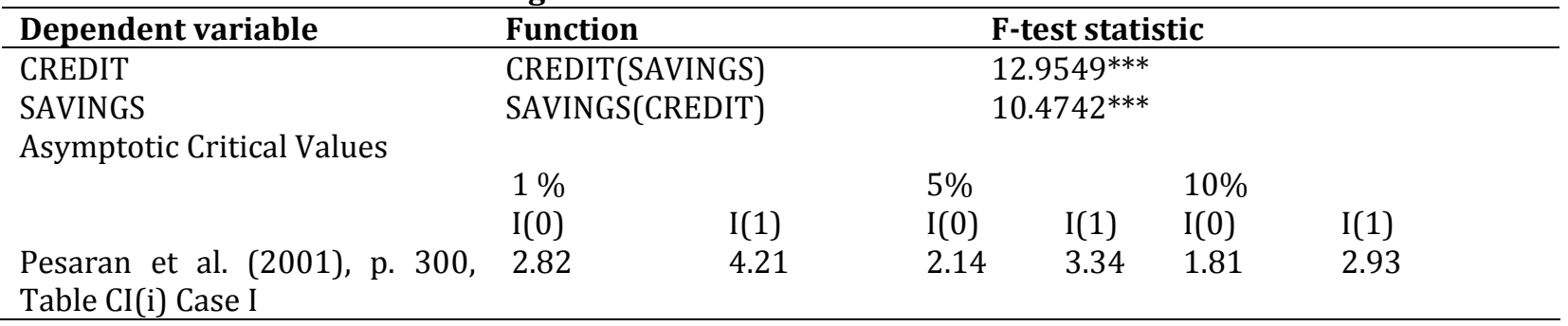

Note: ${ }^{* * *}$ denotes statistical significance at the $1 \%$ level.

Both credit and savings functions in Table 4 show that the two variables are co-integrated. In other words, there exist a long run relationship between savings and financial development in Zimbabwe, consistent with recent literature (Ewetan et al., 2015; Husien, 2007; Baya, 2014; Ang, 2011; Adenutsi, 2011).

Johansen and Juselius Co-Integration Test: Johansen \& Juselius (1990) framework uses both the Maximum Eigenvalue and the Trace test to determine the existence and the number of co-integration vectors. The Johansen and Juselius's co-integration results are contained in Table 5.

Table 5: Johansen co-integration test

\begin{tabular}{|c|c|c|c|c|}
\hline \multicolumn{5}{|c|}{ Unrestricted co-integration rank test (Trace) results } \\
\hline $\begin{array}{l}\text { Hypothesized number of co- } \\
\text { integrated equations }\end{array}$ & Eigenvalue & Trace statistic & $\begin{array}{l}5 \% \text { critical } \\
\text { value }\end{array}$ & Probability \\
\hline None & 0.4110 & $42.0045^{*}$ & 15.4947 & 0.0000 \\
\hline At most 1 & 0.0376 & 2.8346 & 3.8415 & 0.0922 \\
\hline \multicolumn{5}{|c|}{ Unrestricted co-integration rank test (Max-Eigen statistic) results } \\
\hline $\begin{array}{l}\text { Hypothesized number of co- } \\
\text { integrated equations }\end{array}$ & Eigenvalue & $\begin{array}{l}\text { Max-Eigen } \\
\text { statistic }\end{array}$ & $\begin{array}{l}5 \% \text { critical } \\
\text { value }\end{array}$ & Probability \\
\hline None & 0.4110 & 39.1699* & 14.2646 & 0.0000 \\
\hline At most 1 & 0.0376 & 2.8346 & 3.8415 & 0.0922 \\
\hline
\end{tabular}

Notes * refers to the rejection of null hypothesis at, $5 \%$ significance level.

Both trace and max-eigen statistics cannot reject the null hypothesis that says there is at most 1 cointegrating vector in the relationship between savings and financial development for Zimbabwe. In summary, the results from F-Bounds and Johansen co-integration tests concur that there exists a long run relationship between savings and financial development in Zimbabwe during the multicurrency regime period, in support of the theoretical predictions (Schumpeter, 1911; Grossman, 1976; Romer, 1986; Pagano, 1993; Bailliu, 2000; Lucas, 1988).

ARDL Granger causality tests: Following Narayan and Smyth (2008), the following equations provide a framework for Granger causality tests.

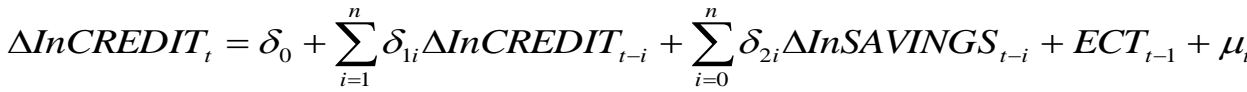

$$
\begin{aligned}
& \Delta \operatorname{InSAVINGS} S_{t}=\phi_{0}+\sum_{i=1}^{n} \phi_{1 i} \Delta \operatorname{InSAVINGS_{t-i}}+\sum_{i=0}^{n} \phi_{2 i} \Delta \operatorname{InCREDIT} T_{t-i}+E C T_{t-1}+\mu_{t}
\end{aligned}
$$

$\mathrm{ECT}_{\mathrm{t}-1}=$ the lagged error-correction term .

Absence of serial correlation in equations 3 and 4 was confirmed by the Breusch-Godfrey Serial Correlation LM Test (results not shown here). The ECT(-1) and F-statistics measure long and short run relationships respectively (see Table 6 for Granger causality results). 
Journal of Economics and Behavioral Studies (ISSN: 2220-6140)

Vol. 9, No. 3, pp. 152-162, June 2017

Table 6: Causality between savings and financial development using ARDL

\begin{tabular}{llll}
\hline Dependent variable & Direction of flow & ECT(-1) statistic & F-statistic \\
\hline CREDIT & SAVINGS $\rightarrow$ CREDIT & $-0.8287^{* * *}$ & $2.0749^{*}$ \\
SAVINGS & CREDIT $\rightarrow$ SAVINGS & $-2.8601^{* *}$ & $3.4720^{*}$ \\
\hline
\end{tabular}

Note: ${ }^{* * *} /{ }^{* *} / *$ denotes statistical significance at the $1 \% / 5 \% / 10 \%$ level respectively.

From Table 6, it shows that feedback effect between savings and financial development occurred both in the long and short run. However, the bi-directional relationship was more significant in the short run than in the long run. The finding is in line with results found by Rezaei et al. (2014) in the case of Iran.

VECM causality analysis: Both long and short run causality VECM tests were performed (see results in Table 7 and 8).

Table 7: Relationship between savings and credit in Zimbabwe using VECM

\begin{tabular}{|c|c|c|c|c|}
\hline \multirow[b]{2}{*}{ Independent variables } & \multicolumn{2}{|c|}{ Dependent variables } & \multirow{2}{*}{\multicolumn{2}{|c|}{$\begin{array}{l}\text { Lag } \\
=5\end{array}$}} \\
\hline & DLCREDIT & DLSAVINGS & & \\
\hline DLCREDIT $(-1)$ & & $0.5146(0.1609)$ & & \\
\hline DLCREDIT(-2) & & $-0.3281(0.3311)$ & & \\
\hline DLCREDIT(-3) & & $-1.7671(0.0000)$ & & \\
\hline DLCREDIT(-4) & & $-1.2940(0.0011)$ & & \\
\hline DLCREDIT(-5) & & $-0.5243(0.1884)$ & & \\
\hline DLSAVINGS $(-1)$ & $0.0401(0.0658)$ & & & \\
\hline DLSAVINGS(-2) & $-0.0139(0.5185)$ & & & \\
\hline DLSAVINGS(-3) & $-0.0136(0.4546)$ & & & \\
\hline DLSAVINGS(-4) & $0.0215(0.2276)$ & & & \\
\hline DLSAVINGS(-5) & $0.0429(0.0132)$ & & & \\
\hline Joint causality [Error correction tem] & $-0.0608(0.0000)$ & $-0.2641(0.0000)$ & & \\
\hline
\end{tabular}

Source: Author's compilation from E-Views analysis

The model in which credit is a dependent variable shows a negative error correction term of -0.0608 which is statistically significant at $1 \%$ level. This means that savings positively and significantly influenced credit in the long run in Zimbabwe. The error correction term is also negative and significant at $1 \%$ level in a model whose dependent variable is savings and credit as an independent variable. This shows that credit significantly Granger caused savings in the long run in Zimbabwe. VECM approach noted the existence of a bi-directional causality relationship between savings and financial development in the long run in Zimbabwe, result which is similar to the ARDL framework finding (see Table 6). Using Wald tests, the study then examined the relationship between savings and credit in the short run, results of which are presented in Table 8.

Table 8: Short run causality between the variables using VECM

\begin{tabular}{lll}
\hline Dependent variable & Direction of flow & F-statistic \\
\hline CREDIT & SAVINGS $\rightarrow$ CREDIT & $2.7872^{* *}$ \\
SAVINGS & CREDIT $\rightarrow$ SAVINGS & $9.0823^{* * *}$ \\
\hline
\end{tabular}

Note: ${ }^{* * *} / * * / *$ denotes statistical significance at the $1 \% / 5 \% / 10 \%$ level respectively.

From Table 8, there exist a bi-directional causality relationship between savings and financial development in the short run in Zimbabwe. These results are in line with those produced by the ARDL approach and shown in Table 6.In summary, savings and financial development affected each other in both short and long run in Zimbabwe. The results are consistent with Rezaei et al. (2014) whose study observed that savings and financial development followed a bi-directional relationship in Iran both in the long and short run.

Diagnostic tests of the VECM models: Table 9 presents the robustness tests results. A model in which credit is a dependent variable and savings is an independent variable shows that there is no serial correlation, data 
is normally distributed, $81.20 \%$ of the data is explained by the model and the data fitted well in the model although there is heteroscedasticity. A model in which savings is a dependent variable whilst credit is an independent variable shows that there is no serial correlation, there is no heteroscedasticity, $61.85 \%$ of the data is explained by the model and the data fitted well in the model. The only weakness of the model is that data is not normally distributed. Given these diagnostic statistics, the paper concludes that the results that were produced from the VECM models are quite robust.

Table 9: Diagnostic tests

\begin{tabular}{|c|c|c|c|c|c|}
\hline $\begin{array}{l}\text { Dependent } \\
\text { variable }\end{array}$ & Test & HO & $\begin{array}{l}\text { Test } \\
\text { statistic }\end{array}$ & P-value & Summary \\
\hline Credit & Serial correlation & $\begin{array}{l}\text { There is no serial } \\
\text { correlation in the } \\
\text { residuals }\end{array}$ & 1.2099 & 0.3163 & No serial correlation \\
\hline Credit & Heteroscedasticity & $\begin{array}{l}\text { There is no } \\
\text { heteroscedasticity in } \\
\text { the residuals }\end{array}$ & 2.1260 & 0.0396 & $\begin{array}{l}\text { There is } \\
\text { heteroscedasticity, } \\
\text { which is not good. }\end{array}$ \\
\hline Credit & Jarque-Bera & $\begin{array}{l}\text { Residuals follow a } \\
\text { normal distribution }\end{array}$ & 14.6183 & 0.1893 & $\begin{array}{l}\text { The errors are } \\
\text { normally distributed }\end{array}$ \\
\hline Credit & R-squared & & $81.20 \%$ & $\mathrm{~N} / \mathrm{A}$ & The model is right \\
\hline Credit & F-statistic & & 24.34 & 0.0000 & $\begin{array}{l}\text { The data has fitted } \\
\text { well in the model }\end{array}$ \\
\hline Savings & Serial correlation & $\begin{array}{l}\text { There is no serial } \\
\text { correlation in the } \\
\text { residuals }\end{array}$ & 2.7457 & 0.1352 & No serial correlation \\
\hline Savings & Heteroscedasticity & $\begin{array}{l}\text { There is no } \\
\text { heteroscedasticity in } \\
\text { the residuals }\end{array}$ & 0.7645 & 0.6835 & $\begin{array}{l}\text { There is no } \\
\text { heteroscedasticity. }\end{array}$ \\
\hline Savings & Jarque-Bera & $\begin{array}{l}\text { Residuals follow a } \\
\text { normal distribution }\end{array}$ & 19.0937 & 0.0067 & $\begin{array}{l}\text { The errors are not } \\
\text { normally distributed }\end{array}$ \\
\hline Savings & R-squared & & $61.85 \%$ & $\mathrm{~N} / \mathrm{A}$ & The model is right \\
\hline Savings & F-statistic & & 6.0946 & 0.0000 & $\begin{array}{l}\text { The data has fitted } \\
\text { well in the model }\end{array}$ \\
\hline
\end{tabular}

Source: Compiled by author

\section{Conclusion}

This paper examined the relationship between savings and financial development in Zimbabwe using both ARDL and VECM approaches for comparison purposes with monthly time series data from January 2009 to August 2015. Four distinct hypotheses emerged from the literature and these are the savings-led financial development, financial development-led savings, feedback effect and the insignificant/no relationship hypothesis. The existence of diverging and contradicting views in empirical literature on the subject matter is evidence that the linkage between savings and financial development is still far from being concluded. Both FBounds and Johansen co-integration tests observed that there is a long run relationship between savings and financial development in Zimbabwe. What is even more unique about this study is that both ARDL and VECM noted the presence of a bi-directional causality relationship between savings and financial development in the short and long run in Zimbabwe. These findings confirmed theoretical predictions. The study therefore urges the Zimbabwe authorities to increase savings mobilisation efforts in order to boost financial development, which in turn is instrumental in spearheading economic growth. Zimbabwe should also implement financial sector development enhancement policies in order to mop up savings and channel them towards the productive sectors of the economy. The weakness of this study is that it only focused on Zimbabwe. It would have been more informative had the study compared Zimbabwe against its Southern African counterparts in as far as savings-financial development nexus is concerned. Such a study can be a subject for future research. 


\section{References}

Adeniyi, O. \& Egwaikhide, F. O. (2013). Savings-investment nexus in developing countries: Does financial development matter? Journal of Economic Development, 38(2), 119-140.

Adenutsi, D. E. (2011). Financial development, bank savings mobilization and economic performance in Ghana: Evidence from a multivariate structural VAR. Development Research and Quantitative Techniques, 2(1), 3-24.

Ang, J. B. (2011). Savings mobilization, financial development and liberalization: The case of Malaysia. Review of Income and Wealth, 57(3), 449-470.

Asamoah, G. N. (2008). The impact of the financial sector reforms on savings, investments and growth of gross domestic product (GDP) in Ghana. International Business and Economics Research Journal, $7(10), 73-$

Baya, Y. (2014). Financial development and domestic savings in emerging Asian countries. Theoretical and Applied Economies, 7(7), 55-66.

Bailliu, J. N. (2000). Private capital flows, financial development and economic growth in developing countries. Working Paper 2000-15. International Department Bank of Canada. pp 1-22.

Bonser-Neal, C. \& Dewenter, K. L. (1999). Does financial market development stimulate savings? Evidence from emerging stock markets. Contemporary Economic Policy, 17(3), 370-380.

Chowdhury, A. (2001). The impact of financial reform on private savings in Bangladesh. Marquette University, Economics Faculty Research and Publications, WIDER-Discussion Papers, No. 78(2001), pp. 1-34.

Edo, S. E. (1995). An estimation of a model of long term securities investment in Nigeria. Nigeria Economic and Financial Review, 1(2), 45-53.

Ewetan, O., Ike, D. N. \& Urhie, E. (2015). Financial sector development and domestic savings in Nigeria: A Bounds testing co-integration approach. International Journal of Research in Humanities and Social Studies, 2(2), 37-44.

Fry, M. J. (1980). Saving, investment, growth and the cost of financial repression. World Development, 8(4), 317-327.

Goldsmith, R. W. (1969). Financial structure and development, Yale University Press, New Haven, CT.

Grossman, S. J. (1976). On the efficiency of competitive stock markets where traders have diverse information. Journal of finance, 31(2), 573-585.

Gungor, H. Ciftcioglu, S. \& Balcilar, M. (2014). Does financial development increase private savings? The case of Turkey. International Journal of Business and Social Science, 5(2), 36-47.

Hair Jr. Black, W. C., Babin, B. J. \& Anderson, R. E. (2014). Multivariate data analysis. Pearson New International Edition. Seventh Edition.

Husien, N. M. (2007). Financial sector development, savings and economic performance: A case study of Lybia. PhD Thesis (School of the Built Environment), University of Salford, Manchester.

Hussein, K., Mohieldin, M. \& Rostom, A. (2017). Savings, financial development and economic growth in the Arab Republic of Egypt revisited. World Bank Group, Office of the senior Vice President for 2013 development agenda UN relations and partnerships. Policy Research Working Paper No. 8020, pp. 135.

Johansen, S. \& Juselius, K. (1990). Maximum likelihood estimation and inference on co-integration -with applications to the demand for money. Oxford Bulletin of Economics and Statistics, 52(2), 169-210.

Kapingura, F. M. (2014). The relationship between financial sector development and savings mobilization in South Africa: An empirical study. Master of Philosophy in Development Finance at Stellenbosch, 1-75.

Kapingura, F. M. \& Alagidede, P. (2016). The relationship between financial sector development and savings mobilization in South Africa: An empirical study. Development Southern Africa, 33(5), 703-718.

Kelly, R. \& Mavrotas, G. (2008). Savings and financial sector development: Panel co-integration evidence from Africa. The European Journal of Finance, 14(7), 563-581.

Khan, A. H. \& Hasan, M. A. (1988). Financial repression, financial development and structure of savings in Pakistan. The Pakistan Development Review, 27(4), 701-713.

King, R. G. \& Levine, R. (1993). Financial intermediation and growth: Theory and evidence, in Mayer, C. and Vives, X. (Eds). Capital Markets and Financial Intermediation, Centre for Economic Policy Research, London, 156-189.

Lucas, R. (1988). On the mechanics of economic development. Journal of Monetary Economics, 22(1), 3-42. 
McKinnon, R. I. (1973). Money and Capital in Economic Development, The Brooklings Institution, Washington, DC.

Miankhel, A. K., Thangavelu, S. M. \& Kalirajan, K. (2009). Foreign direct investment, exports and economic growth in South Asia and selected emerging countries: A multivariate VAR analysis. CCAS Working Paper No. 23. Crawford School of Economics and Government Australian National University.

Narayan, P. K. \& Smyth, R. (2008). Energy consumption and real GDP in G7 countries: New evidence from panel co-integration with structural breaks. Energy Economics, 30(5), 2331-2341.

Newey, W. K. \& West, K. D.(1987). A simple, positive semi-definite, heteroskedasticity and autocorrelation consistent covariance matrix. Econometrica, 55(3), 703-708.

Odhiambo, N. M. (2008). Financial depth, savings and economic growth in Kenya. Economic Modelling, 25(4), 704-713.

Odhiambo, N. M. (2010). Finance-investment-growth nexus in South Africa: an ARDL-bounds testing approach. Economic Change and Restructuring, 43(3), 205-219.

Oloyede, J. A. (2008). Informal financial sector, savings mobilization and rural development in Nigeria: Further evidence from Ekiti state of Nigeria. African Economic and Business Review, 6(1), 35-63.

Pagano, M. (1993). Financial markets and growth: An overview. European Economic Review, 37(2-3), 613-622.

Pesaran, M., Shin, Y. \& Smith, R. (2001). Bounds testing approaches to the analysis of level relationships. Journal of Applied Econometrics, 16(3), 289-326.

Quartey, P. (2005). Financial sector development, savings mobilization and poverty reduction in Ghana. United Nations University-World Institute for Development Economics Research, Research Paper No. 2005/71, 1-119.

Raheem, I. D. \& Oyinlola, M. A. (2016). Savings-investment-financial development trilogy: Evidence from SSA. Journal of Financial Economic Policy, 9(1), 20-33.

Rehman, M. Z., Ali, N. \& Nasir, N. M. (2015). Financial development, savings and economic growth: Evidence from Bahrain using VAR. International Journal of Financial Research, 6(2), 112-123.

Reserve Bank of Zimbabwe. (2017). database on www.rbz.co.zw

Rezaei, M., Tafarojnooroz, N., Zare, M., Akbarzadeh, H. \& Zare, F. (2014). Financial development, savings and economic growth in Iran. Applied Mathematics in Engineering, Management and Technology, September (2014), 1215-1222.

Romer, P. (1986). Increasing returns and long-run growth. Journal of Political Economy, 94(2), 1002-1037.

Sahoo, P. \& Dash, R. K. (2013). Financial sector development and domestic savings in South Asia. Economic Modelling, 33, 388-397.

Schumpeter, J. A. (1911). The Theory of Economic Development, Harvard University Press, Cambridge, MA.

Shaw, E. S. (1973). Financial Deepening in Economic Development. Oxford University Press, New York, NY.

Tsaurai, K. \& Odhiambo, N. M. (2013). Government expenditure and economic growth in Zimbabwe: An ARDL-bounds testing approach. International Journal of Economic Policy in Emerging Economies, 6(1), 78-90. 